\author{
Jolanta Sokolowska \\ Uniwersytet Gdański \\ jolanta.sokolowska@ug.edu.pl
}

\title{
System pedagogiczny Makarenki w kontekście założeń współczesnej pedagogiki ulicy
}

\author{
Summary \\ Makarenko's pedagogical system in the context of \\ premises of the contemporary street pedagogy
}

The subject of this analysis is an attempt to reflect on the pedagogical system of Antoni Makarenko as a pedagogue of street children. Just as the street peddlers of today worked with children whose negative and afflicted relationships with the world have led to an attitude of distrust and dislike. When analyzing his concept, I referred to the thought he had made in "Pedagogical Poem". Confronting the idea against the views of modern street pedagogues, I tried to answer the questions: what does Makarenko share with people working today with this category of children? How much of his ideas worked out almost a century ago are the inspiration for modern street pedagogues? Makarenko, like the street pedigreers of today, was focused on building contacts, appreciated the significance of the meeting, tried to answer real problems and needs of homeless youth. What distinguishes modern street pedagogy from the Makarenko pedagogical system is its critical character. Makarenko's pedagogy, due to ideological dominance (which was not discussed in the pedagogical activity aimed at shaping the planned political consciousness of the charges), lost its emancipatory character.

Słowa kluczowe: prekursorzy pedagogiki ulicy, współczesna pedagogika ulicy, streetworking, emancypacyjny charakter pedagogiki ulicy

Keywords: forerunners of the street pedagogy, contemporary street pedagogy, streetworking, emancipatory character of street pedagogy

Celem niniejszego tekstu jest próba refleksji nad systemem pedagogicznym Antoniego Makarenki jako pedagoga dzieci ulicy. Analizując jego koncepcję, odwołam się do myśli, które zawarł w Poemacie pedagogicznym. Postaram się zderzyć je z poglądami współczesnych pedagogów ulicy, próbując odpowiedzieć na pytania: Co łączy Makarenkę z osobami pracującymi dzisiaj z tą kategorią dzieci? Na ile jego poglądy wypracowane prawie sto lat temu stanowią inspirację dla współczesnych pedagogów ulicy?

Jednym z podstawowych założeń współcześnie działających pedagogów ulicy jest etnokliniczne podejście do problemów dzieci (Gulczyńska 2011: 67; por. Frysztacki, Nóżka, Smagacz-Poziemska (red.) 2011). Etnometodologia zajmuje się badaniem zacho- 
wań użytecznych, które pomimo ich niewątpliwie pozytywnego aspektu, jakim jest to, iż umożliwiają zaspokojenie bieżących potrzeb, nie dają osobom je stosującym możliwości rozwoju (Garfinkel 2007). Skupiając ich aktywność na podejmowaniu działań skoncentrowanych na tym, co „tu i teraz” oddalają je od nabywania kompetencji potrzebnych do radzenia sobie w przyszłości.

Zdaniem pedagogów ulicy, takie podejście do problemów dzieci stwarza szansę na zrozumienie środowiska i obowiązujących w nim wzorców zachowań społecznych (Cueff 2016). Główny cel tego etapu to zdobycie akceptacji otoczenia i uniknięcie odrzucenia. Etap ten poprzedza podjęcie właściwych działań, które - zdaniem pedagogów ulicy - nie powinny polegać na stosowaniu wcześniej opracowanego modelu pracy, lecz na skonstruowaniu planu działań specyficznych dla danego terenu i podmiotów (Gulczyńska 2011). Zgodnie z tymi założeniami pedagodzy współcześnie pracujący z dziećmi ulicy starają się poznać ich wzajemne relacje, miejsca spotkań, strategie przetrwania, stosunek do dorosłych oraz instytucji (Kurzępa 2005).

Wydaje się, że praca Makarenki również przypominała pracę badacza etnoklinicznego, odwołującego się do przeżyć i doświadczeń wychowanków. Zaczynając swoją pedagogię długo zastanawiał się, w jaki sposób skłonić swoich podopiecznych do współpracy, jak zdobyć ich szacunek i posłuch? Co zrobić, aby nawiązać z nimi kontakt?

Tak, jak współcześnie działający pedagodzy ulicy, Makarenko miał świadomość tego, iż dziecko może wyjść z kręgu zachowań użytecznych pod warunkiem, że uświadomi sobie konieczność zmiany. Tutaj właśnie widział swoją rolę jako pedagog. Swoją wiedzę na temat podopiecznych wykorzystywał jako możliwy teren dialogu. Wbrew dość powszechnym przekonaniom reguły relacji Makarenki z podopiecznymi nie były przyjęte z góry, starał się je wypracować, niejako „na bieżąco”, w praktyce. Dlatego uważam, że Makarenko, tak jak współcześni pedagodzy ulicy, prezentował typ postawy, którą określa się jako refleksyjnego praktyka budującego teorię w praktyce: „Głuchy las wokół kolonii, puste pudła naszych domów, dziesięć łóżek polowych, siekiera i łopata służące za narzędzia i pięciu wychowanków negujących w sposób kategoryczny nie tylko naszą pedagogikę, ale całą kulturę ludzką - wszystko to razem wzięte, szczerze mówiąc, nie przypominało w niczym naszego dotychczasowego szkolnego doświadczenia" (Makarenko 1956: 13).

Radziecki pedagog nieustannie przełamywał istniejące stereotypy myślenia i działania pedagogicznego, szczególnie te dotyczące dzieci ulicy. Jako refleksyjny praktyk teorię wypracowywał w praktyce, tworzył system, który był ciągłym poszukiwaniem i odkrywaniem prowadzącym do powstawania teorii w praktyce: „Pierwsze miesiące naszej kolonii były zarówno dla mnie jak i dla moich towarzyszy nie tylko miesiącami bezsilnej rozpaczy i zdenerwowania - były również miesiącami szukania prawdy. W ciągu całego życia nie przeczytałem tylu książek pedagogicznych, ile w zimie roku 1920. (...) Dzięki tej lekturze zdobyłem mocne i dlaczegoś niezachwiane przeświadczenie, że nie mogę posłużyć się żadną nauką, żadną teorią, że teoria musi być wysnuta z całego zespołu realnych zjawisk, których byłem świadkiem. Zrazu może nawet nie tyle zrozumiałem, ile po prostu 
spostrzegłem, że potrzebne mi są nie książkowe formuły, gdyż i tak nie mogę ich zastosować do rzeczywistości, lecz że muszę natychmiast zanalizować sytuację i niezwłocznie przystąpić do działania" (Makarenko 1956: 15).

Wspólnym fundamentem systemu pedagogicznego Makarenki oraz współczesnej pedagogiki ulicy jest kreowanie działań opartych na silnej, pozytywnej relacji z podopiecznymi. Budowanie jej wymagało stałej (rozciągniętej w czasie, systematycznej i przewidywalnej) obecności, zaangażowania, uczestniczenia w „kawałkach” rzeczywistości i codzienności, wysuwania propozycji oraz mediacji, uważnego słuchania, szacunku, akceptacji, zrozumienia i doceniania podopiecznych, ich działań i sukcesów: „Trzy doby przesiedział Burun w malutkiej izdebce obok sypialni, w tej samej, w której w dawnej kolonii mieszkali „opiekunowie”. Nie zamknąłem go. Dał słowo honoru, że bez mego zezwolenia nie będzie wychodził. (...) Burun dotrzymał słowa: nigdy już potem nie kradł ani w kolonii ani gdzie indziej" (Makarenko 1956: 35).

Następne etapy to utrzymanie tej relacji poprzez stałą obecność oraz wytworzenie wspólnoty. Wychowanie w kolektywie stanowiło dla Makarenki podstawową, najbardziej skuteczną formę organizacji procesu wychowania. Uważał, że głównym celem zespołu powinna być wspólna walka o warunki życia, natomiast podstawową formą pracy ma być współdziałanie, a nie rywalizacja: „Wieczorami dyskutowaliśmy, śmieliśmy się, fantazjowaliśmy na temat naszych przygód, opowiadając o poszczególnych emocjonujących wydarzeniach zbliżaliśmy się do siebie, stapialiśmy się w jednolitą całość, której na imię Kolonia Gorkiego" (Makarenko 1956: 41)

Ważnym polem działania pedagogów ulicy są mediacje $\mathrm{z}$ instytucjami. Ich celem jest zagwarantowanie dzieciom realizacji przysługujących im praw, między innymi prawa do świadczeń zdrowotnych i mieszkaniowych, do ochrony oraz wyżywienia. Do zadań pedagoga ulicy należy zwracanie się o pomoc do placówek pomocy społecznej i służby zdrowia w celu zaspokojenia podstawowych i fundamentalnych potrzeb dzieci żyjących w biedzie. Pedagog powinien przekonać instytucje o skuteczności swej pracy oraz pokazać im celowości bezpośredniej współpracy z osobą, która daje gwarancję, że pomoc trafi bezpośrednio do dziecka. Podstawową trudność stanowi konieczność przekonania instytucji o słuszności zasady udzielania pedagogowi bezwarunkowego wsparcia i potwierdzenia, że dziecku przysługują (niezależnie od jego zachowań) nienaruszalne prawa (Cueff 2007: 194-199; por. Kurzeja 2008). Antoni Makarenko również z dużym zaangażowaniem, a nawet $\mathrm{z}$ heroizmem, walczył o zaspokojenia wszelkich niezbędnych potrzeb życiowych swoich podopiecznych. Z prawdziwą determinacją starał się, aby warunki życia dzieci w Kolonii były godziwe. Niezbędne do życia środki organizował różnymi metodami, walczył o przydziały żywności, odzieży a także środki higieny. Bywało, że chcąc utrzymać Kolonię dopuszczał się nie całkiem legalnych sposobów działania, mogących zagrozić jego reputacji a nawet bezpieczeństwu: „W kancelarii (...) napisałem, popełniając przestępstwo, na blankiecie kolonii, że od obywatela Onufrego Wacia otrzymano na poczet należnego od niego podatku - paszy - pudów siedemnaście” (Makarenko 1956: 94). 
Podobną postawę prezentowali inni współpracujący z nim wychowawcy: „Jekatierina Grigorjewna (...) potrafiła wczuć się w całą głębię straszliwej krzywdy, jaką przeklęty, zły los wyrządził tym dzieciom. Ponadto potrafiła ich jakoś dokarmiać: w tajemnicy lekceważąc wszelkie przepisy i zarządzenia Referatu Zaopatrzenia..." (Makarenko 1956: 82).

Tylko dzięki ogromnej determinacji, wewnętrznej sile i wierze w człowieka Makarenko nie poddał się w warunkach skrajnie trudnych: „Dzięki wytężonym zabiegom dyplomatycznym udawało nam się czasem przekonać, uprosić, wyłudzić, przekupić swym nędznym wyglądem, zastraszyć buntem kolonistów - i wtedy przyznawano nam na przykład normy sanatoryjne. Obejmowały one mleko, masę tłuszczów i biały chleb. Oczywiście nie otrzymywaliśmy tego, ale niektóre składniki wodzianki i chleb żytni przywożono w większej ilości. (...) Czasami wywieraliśmy tak silną presję, że udawało się nam otrzymać nawet mięso, wędliny i słodycze; kiedy się jednak okazywało, że moralnie upośledzeni nie mają żadnego prawa do tego zbytku, a mają je wyłącznie upośledzeni umysłowo - życie nasze stawało się jeszcze smutniejsze" (Makarenko 1956: 23).

Walcząc o przydziały dla Kolonii Makarenko często spotykał się z negatywnymi opiniami na temat swoich podopiecznych, niezłomnie stawał $\mathrm{w}$ ich obronie, przełamując funkcjonujące na ich temat stereotypy: „W kolonii nie używaliśmy nigdy takich słów jak „przestępca” i nasza kolonia tak się nigdy nie nazywała” (Makarenko 1956: 24).

Najważniejszym założeniem animacyjnej działalności współczesnych pedagogów ulicy jest praca na pozytywach (Sokołowska 2016: 266-288). Poszukuje się takich potencjałów i możliwości, które pomogą dzieciom osiągnąć określony cel. Pedagodzy ulicy zwracają szczególną uwagę na budowanie relacji, które staną się źródłem wzmocnienia. Ujawniają i doceniają zdolności podopiecznych, podnosząc ich poczucie własnej wartości (Szczepański 2005). Również Makarenko nie koncentrował się na tym, co widać na pierwszy rzut oka, wiedział, że można bardzo wiele osiągnąc skupiając się na mocnych stronach swoich podopiecznych. Cechował go głęboki optymizm pedagogiczny, przekonanie, że w człowieku trzeba widzieć dobro, które nie zawsze łatwo dostrzec: „Zarówno stary jak i nowi koloniści zawsze demonstracyjnie podkreślali, że personel wychowawczy nie jest w stosunku do nich usposobiony wrogo. Główną przyczyną tego nastroju była niewątpliwie praca naszych wychowawców, tak dalece ofiarna i tak bezspornie ciężka, że naprawdę budziła szacunek. Dlatego też koloniści, poza małymi wyjątkami, byli z nami w dobrych stosunkach, uznawali konieczność pracy i nauki szkolnej, rozumieli doskonale, że to nasza wspólna sprawa" (Makarenko 1956: 56).

Według animatorów pracujących na ulicy jednym z najbardziej istotnych czynników procesu wychowania jest kształtowanie krytycznego myślenia i wartościowania. Umiejętności te kształtują się w kontakcie dziecka ze społeczeństwem. Ze spotkania z innym, obcym i „odmiennym”, rodzą się pytania dziecka o własne i innych doświadczenie życiowe. W tworzącą jednorodną całość, monotonną egzystencję dziecka wprowadza się element różnorodności. Jest to wychowanie kształtujące postawę otwartości na to, co „inne” (Cueff 2007: 194-199). Stwarzanie lub po prostu sprzyjanie powstawaniu sytuacji „niewygodnych” dla dziecięcego rozwoju stanowi bardzo pożądaną, swoistą metodę 
aktywizującą w ramach praktyk wychowawczych, bądź stricte edukacyjnych, przebiegających w duchu konstruktywistycznym. Przybierają one formę chwilowych kryzysów mentalnych - stanów, kiedy to równowaga poznawcza, harmonia pozostaje nadwyrężona. Pokłady wiedzy posiadanej przez dziecko wcześniej, składające się na jego cenny kapitał życiowego doświadczenia, wchodzą w kontrolowany konflikt z nowymi cząstkami znaczeniowymi, w efekcie czego powstaje wiedza o nowej jakości - elastyczna i gotowa na dalsze aktualizujące ją modyfikacje (Klus-Stańska, Szczepska-Pustkowska 2009: 469, 472-473). Wszelkie okazje, dające dziecku możliwość, często bardzo wysiłkowej, samodzielnej eksploracji wielu potencjalnych prawd, okazują się intelektualnym wyzwaniem, szansą jego rozwoju.

Choć Makarenko wspomina w swoim dziele o tym, że jego marzeniem jest rozwijanie twórczego myślenia dzieci, w jego systemie pedagogicznym brakowało działań ukierunkowanych na kształtowanie umiejętności krytycznego myślenia i wartościowania. Brak działań nastawionych na kształtowanie postawy otwartości na to, co „inne”, stanowi swoisty rodzaj zniewolenia, ponieważ dziecku nie daje się możliwości wyboru. Powodem takiego stanu rzeczy było ideologiczne zdominowanie systemu pedagogicznego Makarenki. Nie podlegającym dyskusji celem jego działalności pedagogicznej było kształtowanie z góry zaplanowanej świadomości politycznej podopiecznych: „Za duże mieli zaległości w nauce ci nasi pierworodni, toteż z trudem pokonywali zawiłe mądrości arytmetyki i szkolenia politycznego" (Makarenko 1956: 109).

Jego podopieczni nie byli przysposabiani do krytycznego poznawania świata, w tym zgłębiania prawdy o sobie samych oraz otaczającej ich rzeczywistości. Joanna Rutkowiak nazywa ten rodzaj edukacji nauczaniem niepoznawczym (Rutkowiak 2010a). Przystosowawczy model edukacji jest zawsze co najmniej ryzykowny (Rutkowiak 2010b). W tym miejscu można by powołać się na koncepcję pseudowychowania, zaproponowaną przez Jacka Filka. Autor ten, odwołując się do Arystotelesowskiego pojęcia pseudos, określającego byty, które przedstawiają się nie takimi, jakimi są, równocześnie ukrywając to, czym faktycznie są, odnosi je do pojęcia wychowania. Otrzymuje w ten sposób kategorię pseudowychowania, określającą zjawiska przeciwne istocie wychowania, uzurpujące sobie jednak prawo bycia wychowaniem. Z punktu rozważanej tematyki szczególnie interesujące jest forma wychowania nazwana przez Filka wyobcowanym, gdzie zostaje zakwestionowane rozumienie wychowania jako odniesionego do czegoś zewnętrznego względem niego samego, tzn. wszelkie „wychowanie do”, czy „wychowanie dla” tak znamienne dla systemu pedagogicznego Makarenki (Filek 1984: 165-178).

Podsumowując należy podkreślić, że Makarenko, tak jak współcześni pedagodzy ulicy, był nastawiony na budowaniu kontaktu, doceniał znaczenie spotkania, starał się odpowiadać na rzeczywiste problemy i potrzeby bezdomnej młodzieży. Sądzę, że jego propozycja była dostosowana do realiów ówczesnego świata. Pomimo ostrej dyscypliny pozostawiał wychowankom wybór, dotyczący tego, czy chcą zostać w Kolonii. Jako zaangażowany pedagog uważnie wsłuchiwał się w ich problemy, próbował je zrozumieć, wzmacniał mocne strony podopiecznych i na nich budował. To wszystko, co zainwesto- 
wał w swoich podopiecznych - szacunek, wiarę, perspektywę, zaangażowanie w ich sprawy, z czasem przyniosło owoce. Zyskał szacunek wychowanków i stał się autorytetem dla wielu bezdomnych dzieci.

Wspólne cechy współczesnych pedagogów ulicy i Makarenki to zaangażowanie, cierpliwość i wytrwałość działań. Niewątpliwie charakterystyczną cechą radzieckiego pedagoga była charyzmatyczność i siła charakteru. Również współcześnie pracujący streetworkerzy przyjmują, że pracując z młodzieżą narażoną na patologie trzeba być odważnym i silnym emocjonalnie. Osobom charyzmatycznym łatwiej jest stać się w jakiś sposób atrakcyjnym dla ludzi, wśród których pracują (Pospiszyl, Konopczyński 2007). Wspólnym punktem wyjścia przekonań pedagogicznych Makarenki i osób obecnie pracujących z dziećmi ulicy jest humanizm rozumiany jako walka o to, by człowiek znalazł w sobie siłę, aby podnieść się z upadku. Szukanie odpowiedzi na pytania, od czego zależy postępowanie dziecka, jakie motywy kierują jego działaniami, co można i należy uczynić, aby zmienić jego postępowanie i aby on sam zrozumiał, że trzeba je zmienić (Szczepański 2009; por. Olszewska-Baka, Pytka 2000).

Tym, co różni współczesną pedagogikę ulicy od systemu pedagogicznego Makarenki, jest jej krytyczny charakter. Pedagogika Makarenki z powodu ideologicznego zdominowania (niepodlegającym dyskusji celem jego działalności pedagogicznej było kształtowanie z góry zaplanowanej świadomości politycznej podopiecznych) traci swój emancypacyjny charakter. Swoistym paradoksem wydaje się również to, że Makarenko starał się wychować do nowej rzeczywistości - jak to określał - ,nowego człowieka” stosując adaptacyjny model wychowania: „Poszukiwania sił pedagogicznych doprowadziły mnie już prawie do zupełnej rozpaczy; nikt nie chciał poświęcić się sprawie wychowania nowego człowieka" (Makarenko 1956: 11).

\section{Literatura}

Cueff D. (2007), Dzieci ulicy - potrzeby i możliwości oddziaływań. W: I. Pospiszyl, M. Konopczyński (red.), Resocjalizacja - w strone środowiska otwartego. Warszawa, Wydawnictwo Pedagogium.

Cueff D., Dziecko na ulicy. Europejski projekt DAPHNE: Zwalczanie przemocy wobec dzieci ulicy. Przewodnik metodologiczny. http://www.gpas.org.pl/indexfl.html (dostęp: 5.11.2016).

Filek J. (1984), Pseudowychowanie, „Studia Filozoficzne”, 10.

Frysztacki K., Nóżka M., Smagacz-Poziemska M., (red.), (2011), Dzieci ulicy. Procesy marginalizacji i automarginalizacji nieletnich. Kraków, Wydawnictwo Uniwersytetu Jagiellońskiego.

Garfinkel H. (2007), Studia z etnometodologii. Warszawa, Wyd. PWN.

Gulczyńska A. (2011), Koncepcja dziecka na ulicy. Analiza z perspektywy interakcyjnej. W: K. Frysztacki, M. Nóżka, M. Smagacz-Poziemska (red.), Dzieci ulicy. Procesy marginalizacji i automarginalizacji nieletnich. Kraków, Wydawnictwo Uniwersytetu Jagiellońskiego.

Klus-Stańska D., Szczepska-Pustkowska M. (2009), Pedagogika wczesnoszkolna. Dyskursy, problemy, rozwiazania. Warszawa, Wydawnictwa Akademickie i Profesjonalne.

Kurzeja A. (2008), Dzieci ulicy - profilaktyka zagrożeń. Kraków, Oficyna Wydawnicza „Impuls”. 
Kurzępa J. (2005), Praca socjalna na ulicy w warunkach szczególnego ryzyka. W: E. Bielecka (red.), Streetworking. Teoria i praktyka. Warszawa, Wydawnictwo Wyższej Szkoły Pedagogiki Resocjalizacyjnej.

Makarenko A. (1956), Poemat pedagogiczny. Warszawa, Państwowe Zakłady Wydawnictw Szkolnych.

Olszewska-Baka G, Pytka L. (2000), Dzieci ulicy - metodologiczne aspekty profilaktyki interwencyjnej. W: G. Olszewska-Baka (red.), Dzieci ulicy. Problemy, profilaktyka, resocjalizacja. Białystok, Wyd. ERBE.

Pospiszyl I., Konopczyński M., (red.), (2007), Resocjalizacja - w stronę środowiska otwartego. Warszawa, Wydawnictwo Pedagogium.

Rutkowiak J. (2010a), Czy istnieje edukacyjny program ekonomii korporacyjnej? W: A. Kożyczkowska, M. Szczepska-Pustkowska (red.), Człowiek w systemie pomocy. Konteksty i rozwiazania edukacyjne. Gdańsk, Wydawnictwo GWSH.

Rutkowiak J. (2010b), Nauczyciel w dramacie wartości wychowawczych. Problem na pograniczu pedeutologii i ekonomii. W: E. Potulicka, J. Rutkowiak (red.), Neoliberalne uwikłania edukacji. Kraków, Oficyna Wydawnicza „Impuls”.

Sokołowska J. (2016), Pedagogika ulicy jako praca na zasobach. W: E. Czerka-Fortuna, K. Kmita-Zaniewska, A. Zbierzchowska (red.), Zasoby rodziny - wychowanie, poradnictwo, praca socjalna. Gdańsk, Wydawnictwo Naukowe Katedra.

Szczepański T. (2005), Przestrzenie działania pedagoga ulicznego. W: E. Bielecka (red.), Streetworking. Teoria i praktyka. Warszawa, Wydawnictwo Wyższej Szkoły Pedagogiki Resocjalizacyjnej.

Szczepański T. (2009), Pedagogika ulicy jako odpowiedź na potrzeby środowisk marginalizowanych. W: Partnerstwo dla dzieci - czas wolny jako narzędzie zmiany społecznej. Materiał z II Konferencji zorganizowanej przez Fundację Wspólna Droga w MPiPS 8 grudnia 2008, Warszawa. 